\title{
Evaluating building material based thermal comfort of a typical low-cost modular house in India ${ }^{\star}$
}

\author{
Ronita Bardhan $^{\mathrm{a}^{*},}$ Ramit Debnath ${ }^{\mathrm{a}}$ \\ ${ }^{a}$ Centre for Urban Science and Engineering, Indian Institute of Technology Bombay, Mumbai-400076, India
}

\begin{abstract}
'Housing for All by 2022' is an ambitious initiative by the Government of India, to provide affordable and quality housing to the people of economically weaker sections (EWS) and the low-income group (LIG). Modular housing has become the de-facto in this context of low-cost and affordable housing. In this study, we evaluate the thermal comfort of a commercially available modular house with respect to different low-cost building wall materials and window glass panes. Dynamic energy simulations were carried out for Mumbai to analyse the thermal-comfort performance of such houses throughout the year. Results have shown that none of the low-cost building materials were competent enough to meet the ASHRAE-55 standards. However, a combination of glass fibre reinforced gypsum board and a blue tinted glass of a $6 \mathrm{~mm}$ thickness, performed better in thermal comfort in comparison to other materials. This study showed the need for development of efficient low cost building materials in order to address the long-term sustainability of the low cost housing project.
\end{abstract}

(C) 2017 Elsevier Ltd. All rights reserved.

Selection and Peer-review under responsibility of International Conference on Processing of Materials, Minerals and Energy (July 29th - 30th) 2016, Ongole, Andhra Pradesh, India.

Keywords: Building materials; Mean radiant temperature; Operative temperature; Thermal comfort; Low-cost housing; Sustainability

\footnotetext{
* Corresponding author. Tel.: +22-2576-9332

E-mail address: ronita.bardhan@iitb.ac.in
}

\footnotetext{
* This is an open-access article distributed under the terms of the Creative Commons Attribution-NonCommercial-ShareAlike License, which permits non-commercial use, distribution, and reproduction in any medium, provided the original author and source are credited.
}

2214-7853 (C) 2017 Elsevier Ltd. All rights reserved.

Selection and Peer-review under responsibility of International Conference on Processing of Materials, Minerals and Energy (July 29th - 30th) 2016, Ongole, Andhra Pradesh, India. 


\section{Introduction}

The Ministry of Housing and Urban Poverty Alleviation (MHUPA), the Government of India (GoI) in their annual report for the FY- 2014-15, estimated that India suffers from housing shortages by 18.54 million units [1]. $96 \%$ of the housing shortage is in economically weaker sections (EWS) and the low-income group (LIG), who also suffers from lack of basic amenities like sanitation services, potable drinking water, electricity and effective solid waste disposal services [1], [2]. Attempts to mitigate this problem pertaining to the quality of life (QoL), the Ministry announced the National Urban Housing and Habitat Policy, 2007, which focusses on 'affordable housing for all with special emphasis on economically weaker sections of society such as SC, STs, OBCs, Minorities, women-headed households' [1].

In this purview, private corporations have flocked in to cater to this ambitious aim of the MHUPA, by providing modular low-cost houses, with an average floor area of 600 square meters [3]. However, the long-term sustainability of such modular houses is still unidentified, as different strata of the society has varied lifestyles with cultural and social needs. Moreover, current literature lacks building performance analysis in terms of thermal comfort of such modular houses, which can provide valuable insights pertaining to their long-term sustainability, and prepare designers, engineers and investors towards more sustainable low-cost housing design.

In India, where only 7\% of the residential houses uses ACs during the summer months [4], [5], hence maintaining optimal thermal comfort levels becomes a critical sustainability clause, especially for EWS and LIG houses. Thermal comfort is defined as "that condition of mind which expresses satisfaction with the thermal environment" [6]. ASHRAE-55 standards suggest $26^{\circ} \mathrm{C}$ as the desirable indoor temperature for prolonged thermal comfort [7]. Indian codes specify uniform comfort temperatures between 23 and $26^{\circ} \mathrm{C}$ for all types of buildings as the required thermal comfort range [8]. The thermal temperature that our body experience in an indoor space is known as operative temperature $\left(t_{o}\right)$. It is a combined effect of mean radiant temperature $\left(t_{r}\right)$ and the air temperature $\left(t_{d b}\right)$. Mean radiant temperature $\left(t_{r}\right)$, is defined as 'the uniform surface temperature of an imaginary black enclosure in which an occupant would exchange the same amount of radiant heat as in the actual non-uniform space' [9].

Here, we investigated the thermal comfort performance of a commercially available low-cost house with respect to different low-cost building material, with mean radiant temperature $\left(t_{r}\right)$ and operative temperature $\left(t_{o}\right)$ as the performance indicators.
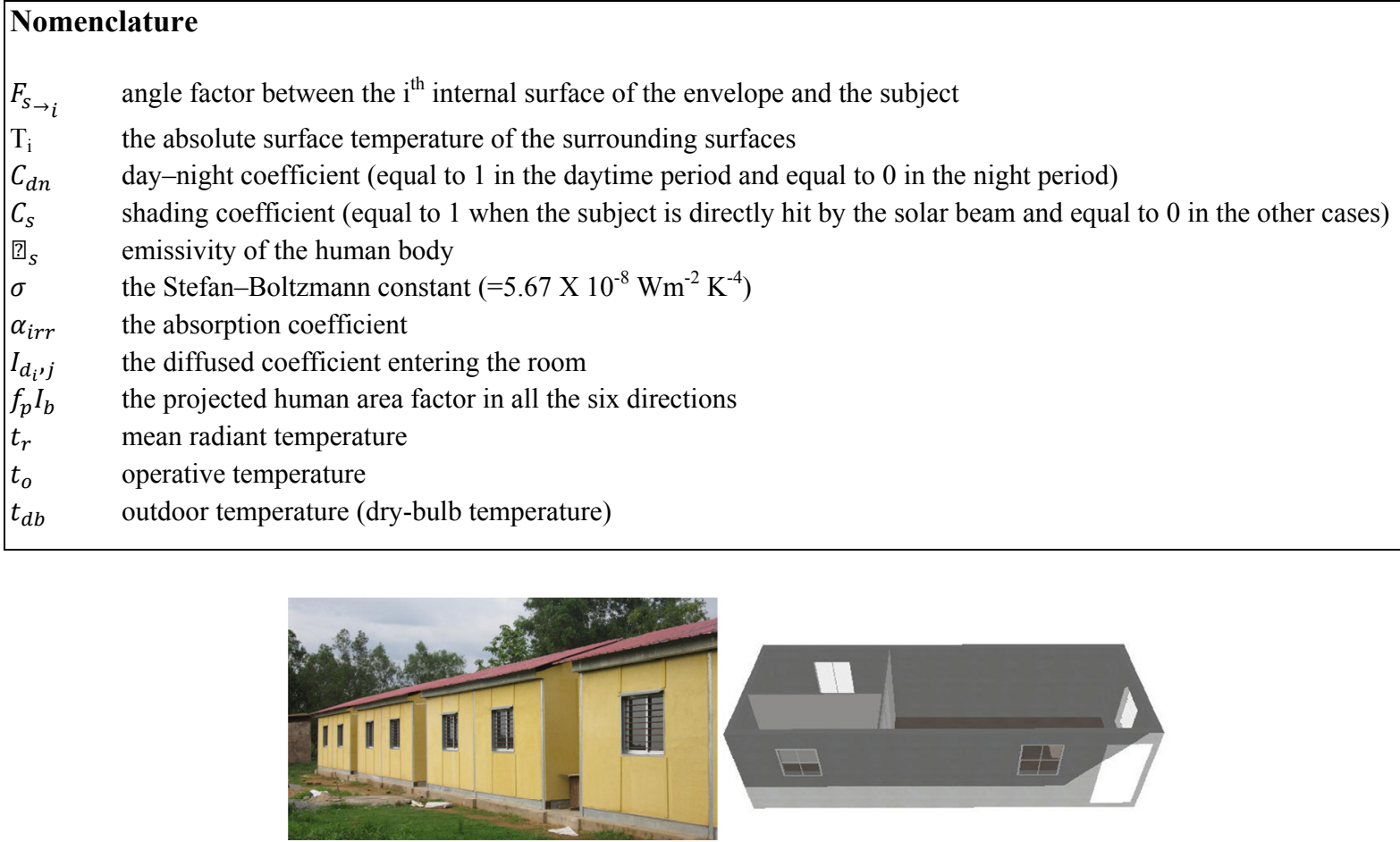

Fig 1. A typical commercially available low-cost modular house in India and its CAD model. [1] 


\section{Methodology}

This study numerically evaluates the thermal performance of a modular low-cost house in India. Here, we simulate a typical low-cost modular house (see Fig 1) with different window glass and external wall materials, and calculate the annual indoor mean radiant temperature and the operative temperature using dynamic energy simulations. Such comparison of thermal performance will assess the 'comfort sustainability' of such houses that uses low cost building materials, and aims to fulfill the requirements of 'Housing for all by 2022' scheme. Thermal comfort analysis is crucial for low cost houses because if the indoor temperature becomes unbearable, then, the occupants will soon abandon them, and the whole concept of housing for all becomes ineffective.

\subsection{Building Modelling}

DesignBuilder v4.7 was used to perform building modelling and simulation using its natural ventilation module. It is a validated and widely used software for studying building performance dynamics and CFD analysis of building environment [10], [11]. It uses EnergyPlus as its core simulation engine, which performs climate based dynamic calculations for the prediction of energy simulation, load calculation, heat balance, and mass balance [10]. Here, we have incorporated EnergyPlus v8.3 for the thermal comfort calculations of the building as illustrated in Fig 1. Table 1 and Table 2 describes the properties of the studied house. Mumbai has a hot and humid climate with a mean average temperature of $27.2^{\circ} \mathrm{C}$ and average precipitation is $242.2 \mathrm{~cm}$ ( 95.35 inches). The mean maximum and minimum average temperatures is about $32^{\circ} \mathrm{C}\left(90^{\circ} \mathrm{F}\right)$ and $25^{\circ} \mathrm{C}\left(77^{\circ} \mathrm{F}\right)$, respectively in summer and in winter, while the average minimums are $30^{\circ} \mathrm{C}\left(86^{\circ} \mathrm{F}\right)$ and $20.5^{\circ} \mathrm{C}\left(68.9^{\circ} \mathrm{F}\right)$ in winter, respectively [12].

Table 1. Physical parameters of a typical modular house

\begin{tabular}{ll}
\hline Parameter & Dimensions \\
\hline Length $(\mathrm{m})$ & 9.14 \\
Breadth $(\mathrm{m})$ & 3.04 \\
Height $(\mathrm{m})$ & 2.60 \\
Overall Area $\left(\mathrm{m}^{2}\right)$ & 30.65 \\
Room (one room) $\left(\mathrm{m}^{2}\right)$ & $6.09 \times 3.04$ \\
Kitchen (one kitchen) $\left(\mathrm{m}^{2}\right)$ & $3.04 \times 1.21$ \\
Toilet (one toilet) $\left(\mathrm{m}^{2}\right)$ & $3.04 \times 1.82$ \\
Window to wall ratio & $8 \%$ \\
\hline
\end{tabular}

Source: [13]

Table 2. Typical commercially available low-cost housing specification

\begin{tabular}{ll}
\hline Building Component & Specifications \\
\hline Structural Steel & $1.2 \mathrm{~mm}$ thick, 275 MPa Strength, C Sections \\
Foundation & Standard foundation of $600 \mathrm{~mm}$ \\
Wall Cladding & Cement Bonded Particle Board on both sides \\
Roofing Sheet & GC sheet \\
Roof type & Gable(Dual) slope \\
Fasteners & Standard fasteners (Galvanized), Self-Drilling Screws. \\
Insulation & High Density Wool Insulation in all walls to provide thermal comfort \\
Flooring & Standard Cemented flooring \\
Doors & Standard Steel Doors \\
Windows & Standard Steel-Net windows \\
External finish & Polymer coating on External boards, to give conventional look and feel \\
Internal finish & Wally Putty finishing on internal walls \\
\hline
\end{tabular}

Source: [13] 


\subsection{Simulations}

Natural ventilation simulations were carried out using EnergyPlus v8.3 for the entire year using ISHRAE, 2013 weather data for Mumbai. The building materials were varied as per popular commercially available wall and glass materials available for low-cost housing (refer Table-3), followed by their thermal comfort calculations $\left(t_{o}\right.$ and $\left.t_{r}\right)$. The $t_{o}$ and $t_{r}$ are given as (see eq. 1 and 2) [14]:

$$
\begin{aligned}
& t_{o}=\frac{\left(t_{r}+t_{d b}\right)}{2} \\
& t_{r}=\sqrt[4]{\sum_{i=1}^{N} F_{S_{\rightarrow i}} T_{i}^{4}+\frac{C_{d n}}{{ }_{s} \sigma}\left(\alpha_{i r r, d} \sum_{j=1}^{M} F_{S_{\rightarrow_{j}}} I_{d_{i}, j}+C_{s} \alpha_{i r r, b} f_{p} I_{b}\right)}
\end{aligned}
$$

Simulations were performed using three different low-cost window glass material and wall materials. The choice of the materials was such that each material could be replaced by the other material for the intended purpose, without changing the total cost of construction or compromising on the desired structural stability of the house. The Table 3 illustrates chosen materials and their properties. Infiltrations were considered in the thermal comfort calculations in the building in the form of minor cracks and gaps, such that the simulations can emulate the real life scenario. The windows are assumed to be kept open $50 \%$ of the time for a comfortable indoor temperature.

Table 3. Low-cost building material and their properties

\begin{tabular}{llll}
\hline \multicolumn{1}{c}{ Wall Material } & $\begin{array}{l}\text { Density } \\
\left(\mathrm{kg} / \mathrm{m}^{3}\right)\end{array}$ & $\begin{array}{l}\text { Specific Heat } \\
(\mathrm{J} / \mathrm{kg}-\mathrm{K})\end{array}$ & $\begin{array}{l}\text { Thermal Conductivity } \\
(\mathrm{W} / \mathrm{m}-\mathrm{K})\end{array}$ \\
\hline W1= Cement bonded particle board & 1200 & 1500 & 0.23 \\
W2= Glass fibre reinforced gypsum panel & 1140 & 840 & 0.617 \\
W3= Gypsum plaster board & 950 & 820 & 0.160 \\
\hline \multicolumn{1}{c}{ Glass types } & $\mathrm{U}-$ Value & Solar Heat Gain & Visual light \\
& $\left(\mathrm{W} / \mathrm{m}^{2}-\mathrm{K}\right)$ & Coeff. (SHGC) & transmittance (VT) \\
\hline I1= Clear glass 3mm & 6.257 & 0.850 & $90 \%$ \\
I2= Clear glass 6mm & 6.121 & 0.810 & $88 \%$ \\
I3= Clear glass 6mm with blue tinted film & 6.121 & 0.587 & $57 \%$ \\
\hline
\end{tabular}

Source: [13], [15], [16]

Table 4. List of simulation models based on different wall and glass material

\begin{tabular}{|c|c|c|c|}
\hline $\mathrm{M}_{\mathrm{ij}}$ & $\mathrm{I} 1$ & $\mathrm{I} 2$ & $\mathrm{I}$ \\
\hline $\mathrm{W} 1$ & $\mathrm{M} 11$ & $\mathrm{M} 12$ & $\mathrm{M} 13$ \\
\hline $\mathrm{W} 2$ & $\mathrm{M} 21$ & $\mathrm{M} 22$ & $\mathrm{M} 23$ \\
\hline $\mathrm{W} 3$ & $\mathrm{M} 31$ & $\mathrm{M} 32$ & $\mathrm{M} 33$ \\
\hline
\end{tabular}

Finally, nine models with varying glass and wall material were simulated as represented in Table 4, where M11 represents the simulation of the original building. For comparison purpose, we modelled the original house with standard brick and mortar wall (termed as M_Brick) with varying glass material, while keeping the other parameters constant. To understand that whether the material change produced significant difference in thermal comfort we performed 'one-way ANOVA' statistical test at 95\% C.I. on the mean radiant and operative temperature.

\section{Results}

The simulated results have shown that building wall materials played a more significant role in enhancing thermal comfort than changing the window glass type. However, it has to be noted that only low-cost commercially available materials were chosen to evaluate the thermal comfort performance. Out of the nine models the wall material "Glass fibre reinforced gypsum panel (W2)" performed better than other two wall materials in providing 
relative thermal comfort. Very little variation was observed when the materials of the glass were varied. The $6 \mathrm{~mm}$ glass with blue tinted film performed relatively better than the clear glass of a $3 \mathrm{~mm}$ and a $6 \mathrm{~mm}$ thickness, respectively (refer Fig. 2-7).

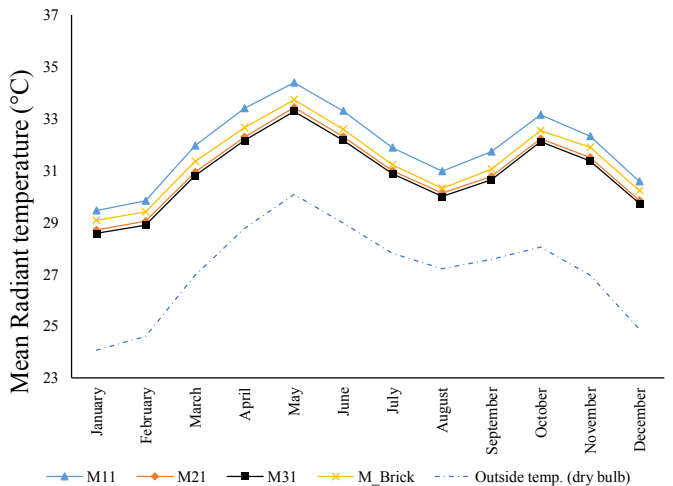

Fig 2. Differences in the mean radian temperature with respect to different wall materials and $3 \mathrm{~mm}$ clear window glass.

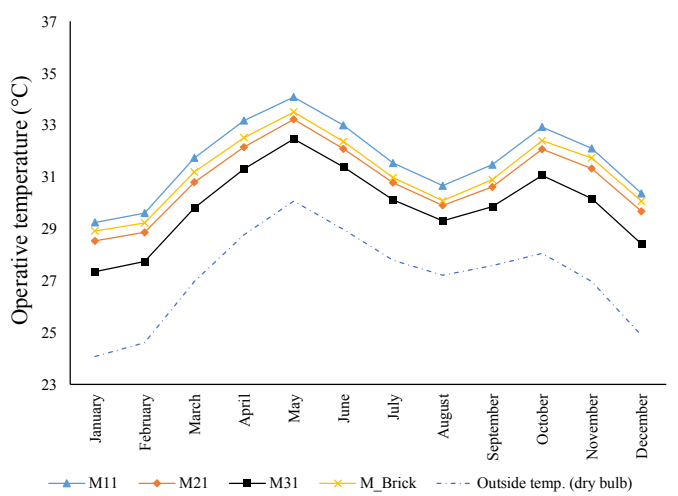

Fig 3. Differences in the operative temperature with different wall materials and $3 \mathrm{~mm}$ clear glass in the windows.

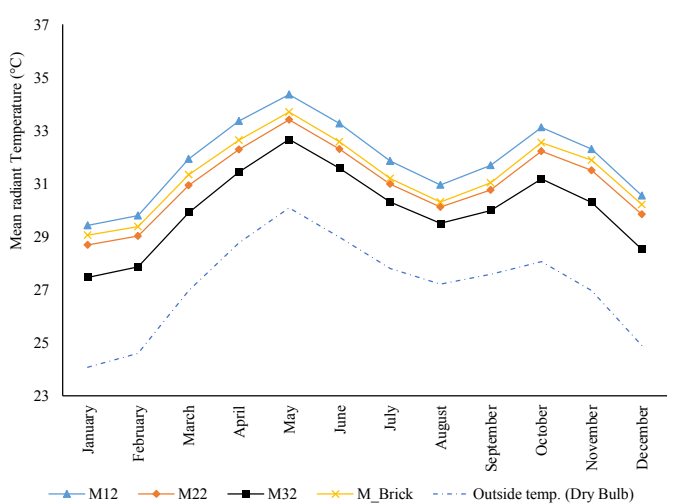

Fig 4. Differences in the mean radian temperature with respect to different wall materials and $6 \mathrm{~mm}$ clear window glass.

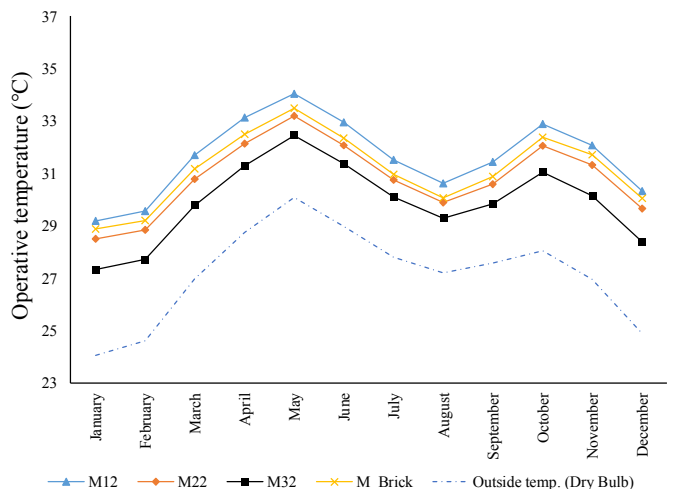

Fig 5. Differences in the operative temperature with respect to different wall materials and $6 \mathrm{~mm}$ clear window glass.

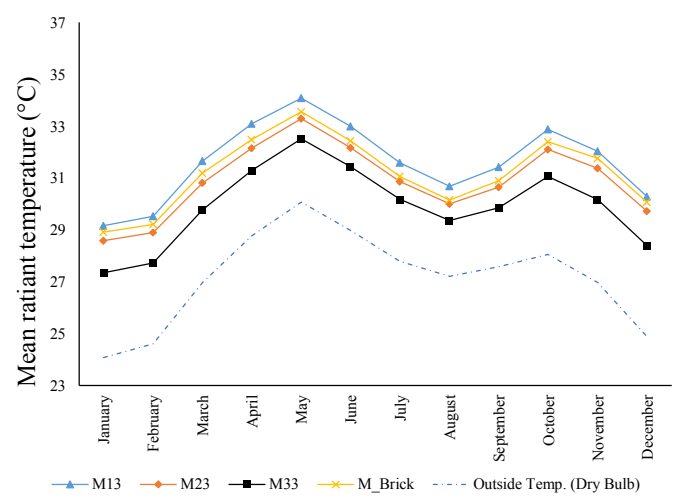

Fig 6. Differences in the mean radian temperature with respect to different wall materials and $6 \mathrm{~mm}$ clear window glass with blue tint.

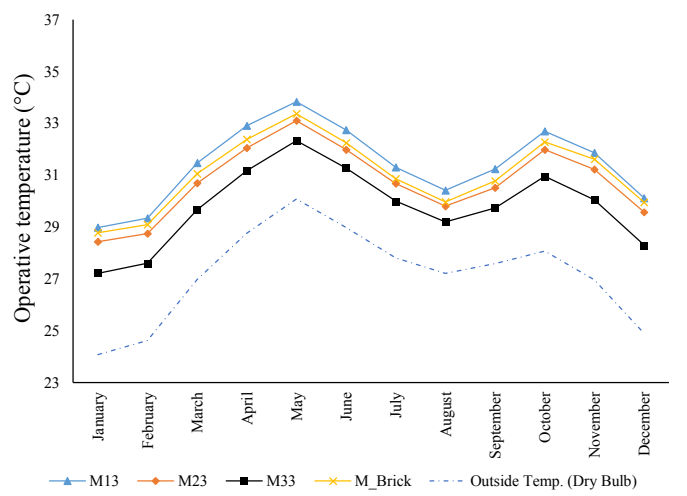

Fig 7. Differences in the operative temperature with respect to different wall materials and $6 \mathrm{~mm}$ clear window glass with blue tint. 
Results from ANOVA revealed that significant variation was observed in operative temperature when the wall material was changed while keeping the glass material constant. In case of mean radiant temperature variation in thermal comfort performance of clear glass of $3 \mathrm{~mm}$ was not significantly different at 95\% C.I. Table 5 and Table 6 illustrates the results of ANOVA.

Table 5. Variation of operative temperature $\left(t_{o}\right)$ for simulated wall materials with respect to glass materials

\begin{tabular}{lllllll}
\hline Glass material & SS & df & MS & F & P-value & F crit \\
\hline Clear Glass of 3mm width & 18.25 & 2.00 & 9.13 & 4.14 & 0.02 & 3.28 \\
Clear Glass of 6mm width & 17.87 & 2.00 & 8.93 & 4.04 & 0.03 & 3.28 \\
Clear glass 6mm with blue tinted film & 15.81 & 2.00 & 7.90 & 3.58 & 0.04 & 3.28 \\
\hline
\end{tabular}

Table 6. Variation of mean radiant temperature $\left(t_{r}\right)$ for simulated wall materials with respect to glass materials

\begin{tabular}{lllllll}
\hline Glass material & SS & df & MS & F & P-value & F crit \\
\hline Clear Glass of 3mm width & 7.55 & 2.00 & 3.78 & 1.79 & 0.18 & 3.28 \\
Clear Glass of 6mm width & 19.81 & 2.00 & 9.91 & 4.43 & 0.02 & 3.28 \\
Clear glass 6mm with blue tinted film & 17.26 & 2.00 & 8.63 & 3.86 & 0.03 & 3.28 \\
\hline
\end{tabular}

\section{Conclusion}

In this study, we had evaluated the thermal performance of popular low-cost building materials in providing yearlong thermal-comfort conditions in the houses constructed out of them. Low-cost housing is an important emerging sector, where both public and private institutions are keen on availing investment opportunities towards the ambitious 'Housing for All by 2022' scheme of GoI. Here, we found that the popular low cost building materials, are ineffective in maintaining indoor thermal comfort levels as per the ASHRAE-55 standards. This can drive the occupants either to shift to high priced conventional houses or resort to sprawling, hence defeating the whole purpose of the 'Housing for All' agenda. Future work lies in testing low-cost building materials that can provide structural, thermal and energy efficiency and arriving at indoor thermal comfort thresholds based on the occupant's preferences in local climatic conditions.

\section{Acknowledgement}

The material presented in this manuscript is based in part upon the work supported by the Ministry of Human Resource Development, Government of India (GoI) under the project FAST (14MHRD005). Any opinions, findings, and conclusions or recommendations expressed in this material are those of the authors and do not necessarily reflect the views of the MHRD and/or IIT Bombay.

\section{Reference}

[1] Ministry of Housing and Urban Poverty Alleviation, “Annual Report 2014-15,” New Delhi, 2015.

[2] R. Bardhan, S. Sarkar, A. Jana, and N. R. Velaga, "Mumbai slums since independence: Evaluating the policy outcomes," Habitat Int., vol. 50, pp. 1-11, 2015.

[3] KPMG India, “Affordable Housing - A key growth driver in the real estate sector?," KMPG India, pp. 1-20, 2010. Retreived:

http://www.kpmg.com/IN/en/IssuesAndInsights/ThoughtLeadership/Affordable_Housing.pdf [accessed: 30May-2016]. 
[4] Government of India, "The Final Report of the Expert Group on Low Carbon Strategies for Inclusive Growth,” 2014 Retreived: http://planningcommission.nic.in/reports/genrep/rep_carbon2005.pdf [Accessed: 30-May-2016].

[5] R. Bardhan and R. Debnath, "Towards daylight inclusive bye-law: Daylight as an energy saving route for affordable housing in India,” Energy Sustain. Dev., vol. 34, no. October 2016, pp. 1-9, 2016. dx.doi.org/10.1016/j.esd.2016.06.005.

[6] ISO 7730:2005, "Moderate Thermal Environments - Determination of the PMV and PPD indices and specification of the conditions for thermal comfort," Zurich, 2015.

[7] R. J. De Dear and G.S. Brager, "Thermal comfort in naturally ventilated buildings: revision to ASHRAE standards 55,” J. Energy Build., vol. 34, pp. 549-561, 2002.

[8] M. Indraganti, “Adaptive use of natural ventilation for thermal comfort in Indian apartments," Build. Environ., vol. 45, no. 6, pp. 1490-1507, 2010.

[9] R. de Dear, "Recent enhancements to the adaptive comfort standard in ASHRAE 55-2010," Proc. 45th Annu. Conf. Archit. Sci. Assoc., no. 1998, 2011.

[10] R. Debnath, R. Bardhan, and R. Banerjee, "Investigating the age of air in rural Indian kitchens for sustainable built-environment design," J. Build. Eng., vol. 7, pp. 320-333, 2016.

[11] Designbuilder, "DesignBuilder Simulation + CFD Training Guide," pp. 1-224, 2011 [Accessed: 30-May2016].

[12] Ministry of Earth Science, "Regional meterological Centre Mumbai," 2016. [Online]. Available: http://www.imdmumbai.gov.in/. [Accessed: 30-May-2016].

[13] BMTPC, Emerging Housing Technologies. New Delhi: Ministry of Housing \& Urban Poverty Alleviation, 2015. Retreived: http://www.bmtpc.org/ [Accessed: 22-May-2016]

[14] M. La Gennusa, A. Nucara, G. Rizzo, and G. Scaccianoce, "The calculation of the mean radiant temperature of a subject exposed to the solar radiation - A generalised algorithm," Build. Environ., vol. 40, no. 3, pp. 367-375, 2005.

[15] J. K. Nayak and J.Prajapati, “Handbook on Energy Conscious Buildings," New Delhi, India, 2006.

[16] VDI Buch, VDI Heat Atlas. Berlin, Heidelberg: Springer Berlin Heidelberg, 2010. 